\title{
A STUDY OF CLINICOPATHOLOGICAL SIGNIFICANCE AND SHORT TERM COMPLICATIONS OF LEVEL III AXILLARY LYMPH NODE DISSECTION IN EARLY BREAST CARCINOMA.
}

\author{
Dr. Mainak Mallik Department of General Surgery, Medical College \& Hospital, Kolkata. \\ Dr. Vikram \\ Chaturvedi* \\ Department of Surgical Oncology, Medical College \& Hospital, Kolkata. \\ ${ }^{*}$ Corresponding Author \\ Dr. S J Ghosh \\ Department of General Surgery, Medical College \& Hospital, Kolkata. \\ Dr. S K Ghosh \\ Department of Surgical Oncology, Medical College \& Hospital, Kolkata.
}

\section{KEYWORDS :}

\section{INTRODUCTION:}

Breast cancer is the most common site-specific cancer in women and is the leading cause of death from cancer for women aged $20-59$ years. It accounts for $26 \%$ of all newly diagnosed cancers in females and is responsible for $15 \%$ of the cancer-related deaths in women. Presently, 75,000 new cases occur in Indian women every year. Locally advanced breast cancer (LABC) constitutes more than 50 to $70 \%$ of the patients presenting for treatment.

The tumor is highly heterogeneous, with a wide range of biological, pathological and clinical characteristics. There is a lot of data on prognostic ${ }^{17}$ and predictive factors for breast cancer. A prognostic factor is any measurement available at or before the time of surgery that correlates with disease-free or overall survival in the absence of systemic adjuvant therapy and, as a result, is able to correlate with the natural history of the disease. In contrast, a predictive factor is any measurement associated with response to a given therapy.

The International Consensus Panel of St. Gallen determined the standard prognostic factors of breast cancer as follows: 1 Lymph node status,

2 Tumour size,

3 Histological grade,

4 Hormone receptor status and

5 Age

Evaluation of axillary lymph node status by sentinel lymph node biopsy and subsequent axillary lymph node dissection (ALND) are an integral part of breast cancer treatment ${ }^{1}$. Increased understanding of the tumour biology has changed the prognostic and therapeutic impact of the lymph node status ${ }^{2,3}$. On the other hand non-invasive imaging techniques like axillary ultrasound, FDG-PET, or MRI scans are not reliable for axillary nodal staging, particularly with size of metastasis $<5 \mathrm{~mm}$.

The two basic principles of treatment are to reduce the chance of local recurrence and the risk of metastatic spread. Treatment of early breast cancer will usually involve surgery (BCS) with radiotherapy.

It has been noticed that with without adequate clearance of positive axillary nodes, recurrence rates have been reported to be as high as $18.6 \%$.

Early breast carcinoma according to the TNM classification strictly confines to stages I to IIB . In this group, patients present mainly with clinically node negative axilla ${ }^{12}$. ALND is performed in $\operatorname{SLNB}^{8,9,10}(+)$ patients for staging purposes and to guide subsequent adjuvant therapy.

Earlier tumour size $\left(<2 \mathrm{~cm} />2 \mathrm{~cm}\right.$ ) along with grade ${ }^{11} \&$ site $^{7}$ of the tumour, was associated with a higher probability of axillary nodal metastasis, but recent studies have shown that molecular profile of primary breast tumour has a greater prognostic significance in terms of disease free and overall survival as compared to nodal metastasis.

Morbidity of ALND includes early and late complications. Early complications include haemorrhage, hematoma, seroma, wound infection, skin flap necrosis, paresthesia, edema of arm, and muscle paralysis.

Late complications include chronic lymphedema, chronic pain, stiffness and weakness of shoulder with disability of the $\operatorname{arm}^{4,5,6}$.

Axillary lymph node status remains the most important prognostic factor of breast carcinoma. Complete axillary clearance provides the most accurate information about nodal status but is mostly considered for staging purpose ${ }^{(1)}$.

An assessment of correlation between various clinicopathological features and axillary lymph node metastasis in Early Breast Cancer was done in Medical College \& Hospital, Kolkata, from August 2017 to August 2019, to gain better insight into its prognostication in breast carcinoma, considering that nodal metastasis is the single best prognostic indicator in breast carcinoma.

\section{AIMS AND OBJECTIVES:}

The primary objectives of this study was to assess the clinicopathological significance of level III axillary lymph node involvement in early carcinoma breast along with the associated short term complications.

\section{SPECIFIC OBJECTIVES :}

1.To determine whether complete axillary lymph node dissection $^{13}$ upto level III lymph nodes help in staging of the disease and evaluate its importance as a routine procedure in early breast cancer.

2.To determine the short term postoperative complications and morbidities associated with level $\mathrm{III}^{18}$ axillary lymph node dissection (complications like intraoperative bleeding, nerve injury during dissection, myotomy if required, surgical site infection, flap necrosis, seroma formation, and numbness or paraesthesia of the ipsilateral arm \& axilla).

\section{MATERIALS AND METHODS:}

a) Study Area: Medical College and Hospital, Kolkata.

b) Study Population: Patients admitted at $\mathrm{MCH}$ General Surgery \& Surgical Oncology wards. 
d) Sample Size: 50 patients.

Inclusion Criteria :

1. AGE-21 Years or more.

2. GENDER-female.

3. Disease characteristics - histologically confirmed stage I or

II $\left(\mathrm{T}_{1} \mathrm{~T} 3, \mathrm{~N}_{0}\right.$ or $\left.\mathrm{N}_{1} \mathrm{M}_{0}\right)$.

4. Cytologic diagnosis suggestive of carcinoma on FNAC from a breast lesion.

5. A written informed consent prior to study was taken from all patients for Sentinel Lymph Node sampling (using methylene blue dye injected peritumorally) $+/-\mathrm{ALND}^{14}$.

Exclusion Criteria :

1.Patient not giving consent .

2. Locally advanced Breast Cancer needing NACT for downstaging.

3. Evidence of metastatic disease.

4. Concurrent $\mathrm{B} / \mathrm{L}$ breast malignancies.

5. Matted lymph nodes or gross extra nodal disease.

6. Poor surgical risk due to other non malignant systemic diseases.

7. Other prior malignancies within past 5 years.

8. Pregnancy or lactation.

9. Other medical conditions contraindicating post operative breast radiotherapy.

10. Received prior chemotherapy for this breast cancer

11. Received prior selective estrogen receptor modulators therapy ( Tamoxifen/ Raloxifene) for breast tumour.

12. Breast implant present.

13. Prior ipsilateral axillary surgery ( eg-excision biopsy of the lymph nodes or treatment of hidradenitis ).

\section{RESULTS AND ANALYSIS}

In this study, 50 female patients of breast cancer were studied.

AGE:-

Mean age was 49.00 years with standard deviation (S.D.)

7.524 years. The range was from 32 to 65 years.

Table 1: Age Distribution

\begin{tabular}{|l|l|l|}
\hline $\begin{array}{l}\text { AGE GROUPS } \\
\text { (YEARS) }\end{array}$ & $\begin{array}{l}\text { FREQUENCY/ } \\
\text { NO. OF CASES }\end{array}$ & PERCENTAGE (\%) \\
\hline$<35$ & 1 & 02 \\
\hline$\geq 35$ BUT $<50$ & 26 & 52 \\
\hline$\geq 50$ & 23 & 46 \\
\hline
\end{tabular}

SIDE OF BREASTT (LT./RT./BILATERAL):-

25 cases presented with (L) sided \& the other 25 with ( R ) sided tumours .

Clinical Stage:-

Table 2: Frequency Distribution of Clinical Stage

\begin{tabular}{|l|l|l|}
\hline STAGE & FREQUENCY/ NO. OF CASES & PERCENTAGE (\%) \\
\hline IA & 16 & 32 \\
\hline IB & 00 & 00 \\
\hline IIA & 25 & 50 \\
\hline IIB & 09 & 18 \\
\hline
\end{tabular}

\section{SURGICAL MARGINS OF RESECTION :}

In 6 patients (12\%), the surgical margins of resection were involved by malignant cells on final Histopathological report.

AXILLARY NODAL STATUS :-

Out of 50 patients who underwent Sentinel Lymph Node Sampling,

19 patients (38\%) showed LEVEL I axillary node positivity,

13 patients (26\%) showed LEVEL II nodes positive on HPE

12 patients (24\%) showed LEVEL III nodes positive for metastasis on HPE,

06 patients (12\%) showed reactive hyperplasia on final HPE report.
DISTRIBUTION OF LEVEL III L.N. POSITIVITY WITH ĀGE:

Out of 12 cases with LEVEL III positive nodes, the mean age was 49.17 years with standard deviation of 7.22 years.

Table 3 : Frequency of Age Distribution with level III L.N. positivity

\begin{tabular}{|l|l|l|}
\hline $\begin{array}{l}\text { AGE GROUPS } \\
\text { (YEARS) }\end{array}$ & $\begin{array}{l}\text { NO. OF CASES } \\
\text { WITH LEVEL III } \\
\text { POSITIVITY }\end{array}$ & PERCENTAGE (\%) \\
\hline$<50$ & 05 & 41.67 \\
\hline$\geq 50$ & 07 & 58.33 \\
\hline
\end{tabular}

DISTRIBUTION OF THE TYPE OF PATHOLOGY ON HPE :

INTRADUCTAL CA comprised 34 (68\%) of all cases .

Table 4: Distribution Of Pathology On HPE.

\begin{tabular}{|l|l|l|}
\hline PATHOLOGY ON HPE & $\begin{array}{l}\text { FREQUENCY/ } \\
\text { NO. OF CASES }\end{array}$ & $\begin{array}{l}\text { PERCENTAGE } \\
(\%)\end{array}$ \\
\hline $\begin{array}{l}\text { BENIGN CAUSES } \\
\text { (ANDI/Fibroadenoma) }\end{array}$ & 02 & 04 \\
\hline DUCTAL CA & 34 & 68 \\
\hline LOBULAR CA & 05 & 10 \\
\hline $\begin{array}{l}\text { ADENOID CYSTIC } \\
\text { CA }\end{array}$ & 05 & 10 \\
\hline MEDULLARY CA & 01 & 02 \\
\hline ALVEOLAR CA & 01 & 02 \\
\hline PAPILLARY CA & 02 & 04 \\
\hline
\end{tabular}

COMPLICATIONS :-

The complications (short term perioperative) tabulated (with consideration of multiple responses) were as follows:

Table 5: Frequency Distribution Of Complications.

\begin{tabular}{|l|l|l|}
\hline COMPLICATIONS & $\begin{array}{l}\text { FREQUENCY/ } \\
\text { NO. OF CASES }\end{array}$ & PERCENTAGE (\%) \\
\hline $\begin{array}{l}\text { INTRA OPERATIVE } \\
\text { HAEMORRHAGE }\end{array}$ & 02 & 04 \\
\hline $\begin{array}{l}\text { INTRA OPERATIVE } \\
\text { NERVE INJURY }\end{array}$ & 03 & 06 \\
\hline SEROMA & 09 & 18 \\
\hline $\begin{array}{l}\text { FLAP } \\
\text { NECROSIS(Partial) }\end{array}$ & 14 & 28 \\
\hline PARESTHESIA & 12 & 24 \\
\hline LYMPHOEDEMA & 06 & 12 \\
\hline WOUND INFECTION & 01 & 02 \\
\hline NIL & 14 & 28 \\
\hline
\end{tabular}

DISTRIBUTION OF TYPES OF PATTHOLOGY WITH MEAN AGE \& LEVEL III L.N. POSITIVITY:

Table 6 : Distribution of PATHOLOGICAL TYPES with MEAN AGE , LEVEL III L.N. POSITIVITY.

\begin{tabular}{|l|l|l|l|}
\hline PATHOLOGY ON HPE & $\begin{array}{l}\text { MEAN } \\
\text { AGE (IN } \\
\text { YEARS) }\end{array}$ & $\begin{array}{l}\text { LEVEL III L. N. } \\
\text { POSITIVITY } \\
\text { (TOTAL + VE } \\
=12)\end{array}$ & $\begin{array}{l}\text { \% OF } \\
\text { LEVEL III } \\
\text { L.N. } \\
\text { POSITIVITY }\end{array}$ \\
\hline $\begin{array}{l}\text { BENIGN CAUSES } \\
\text { (ANDI/Fibroadenoma) }\end{array}$ & 46.50 & 00 & 00 \\
\hline DUCTAL CA & 51.03 & 11 & 91.67 \\
\hline LOBULAR CA & 40.20 & 01 & 08.33 \\
\hline ADENOID CYSTIC CA & 50.00 & 00 & 00 \\
\hline MEDULLARY CA & 39.00 & 00 & 00 \\
\hline ALVEOLAR CA & 44.00 & 00 & 00 \\
\hline PAPILLARY CA & 44.00 & 00 & 00 \\
\hline
\end{tabular}

ANALYSIS OF LEVEL III L.N. POSITIVITY IN DUCTAL \& NONDUCTAL CA :

A statistical analysis of LEVEL III L.N. POSITIVITY in DUCTAL CA against NON-DUCTAL CA is done with CHI-SQUARE tables, calculation of expected frequency \& the CHI-SQUARE VALUE to note it's statistical significance : 
Table 7: CHI-SQUARE table to analyze LEVEL III L.N. POSITIVITY in DUCTAL vs NON-DUCTAL CA.

\begin{tabular}{|c|c|c|c|}
\hline $\begin{array}{l}\text { NO. OF } \\
\text { CASSES }\end{array}$ & \begin{tabular}{|l|} 
DUCTAL CA \\
$(\bar{A})$
\end{tabular} & $\begin{array}{l}\text { NON-DUCTAL } \\
\text { CA (B) }\end{array}$ & $\begin{array}{l}\text { TOTAL CĀSES } \\
(\mathrm{C}+\mathrm{D})\end{array}$ \\
\hline $\begin{array}{l}\text { LEVEL III } \\
+\mathrm{VE}(\mathrm{C})\end{array}$ & $11(\mathrm{~W})$ & $01(X)$ & $12(\mathrm{C})$ \\
\hline \begin{tabular}{|l} 
LEVEL III - \\
VE(D) \\
\end{tabular} & $23(\mathrm{Y})$ & $15(Z)$ & 38(D) \\
\hline $\begin{array}{l}\text { TOTAL CA } \\
(\bar{A}+\mathrm{B})\end{array}$ & $34(\bar{A})$ & 16(B) & $50(\bar{A}+\mathrm{B}=\mathrm{C}+\mathrm{D})$ \\
\hline
\end{tabular}

Expected Frequency -

$\mathrm{W}=(\mathrm{C} * \mathrm{~A}) / 50=8.16$

$\mathrm{X}=(\mathrm{C} * \mathrm{~B}) / 50=3.84$

$\mathrm{Y}=\left(\mathrm{D}{ }^{*} \mathrm{~A}\right) / 50=25.84$

\section{$\mathrm{Z}=(\mathrm{D} * \mathrm{~B}) / 50=12.16$}

Chi-square Value -

$=(11-\mathrm{W})^{2} / \mathrm{W}+(01-\mathrm{X})^{2} / \mathrm{X}+(23-\mathrm{Y})^{2} / \mathrm{Y}+(38-\mathrm{D})^{2} / \mathrm{D}$

$=4.1$ (which is $>3.84$ i.e. significant)

This signifies that LEVEL III L.N. positivity per HPE is significantly higher in ductal CA than in non-ductal CA at $5 \%$ levels.

\section{DISTRIBUTION OF TYPES OF PATHOLOGY WITH COMPLICATIONS:}

To show the complications against type of pathology, a composite distribution table with line diagram is used.

Table 8: Distribution Of Types Of Pathology With Complications

\begin{tabular}{|c|c|c|c|c|c|c|c|c|}
\hline $\begin{array}{l}\text { Complications } \\
\text { (y Axis) Vs Pathology } \\
\text { (x Axis) }\end{array}$ & $\begin{array}{l}\text { INTRA-OP. } \\
\text { HAEMOR- } \\
\text { RHAGE }\end{array}$ & $\begin{array}{l}\text { INTRA-OP. NV. } \\
\text { INJURY }\end{array}$ & SEROMA & $\begin{array}{l}\text { FLAP NECR- } \\
\text { OSIS } \\
\text { (PARTIAL) }\end{array}$ & $\begin{array}{l}\text { PARAES- } \\
\text { THESIA }\end{array}$ & \begin{tabular}{|l} 
LYMPH- \\
OEDEMA
\end{tabular} & \begin{tabular}{|l} 
WOUND \\
INFECTI-ON
\end{tabular} & NIL \\
\hline BENIGN CONDITIONS & 00 & 00 & 00 & 01 & 01 & 01 & 00 & 00 \\
\hline DUCTAL CA & 02 & 01 & 07 & 10 & 08 & 01 & 00 & 10 \\
\hline PAPILLARY CA & 00 & 00 & 02 & 01 & 01 & 00 & 00 & 00 \\
\hline $\begin{array}{l}\text { ALVEOLAR CA } \\
\end{array}$ & 00 & 00 & 00 & 00 & 00 & 01 & 00 & 00 \\
\hline \begin{tabular}{|l} 
ADENOID CYSTIC CA \\
\end{tabular} & 00 & 00 & 00 & 01 & 00 & 01 & 01 & 02 \\
\hline MEDULLARY CA & 00 & 00 & 00 & 00 & 00 & 00 & 00 & 01 \\
\hline LOBULAR CA & 00 & 02 & 00 & 01 & 02 & 02 & 00 & 01 \\
\hline
\end{tabular}

\section{DISCUSSION:}

Early breast cancer (EBC) constitutes $30 \%$ of breast cancer cases seen at regional cancer centres in India ${ }^{15}$. Axillary lymph node dissection (ALND) following positive $\mathrm{SLNB}^{19}$ is the gold standard in evaluation of axillary lymph node metastases and is an integral part of the treatment of breast cancer. It provides benefit for breast cancer patients by rendering regional control and may improve overall survival by surgical removal of microscopic nodal metastases ${ }^{1}$. Because of wide array of treatment options available today, the number of positive lymph nodes have important implications in choosing the right treatment strategy.

In this study regarding LEVEL III ALND in early CA breast, two parameters were evaluated - the clinico-pathological significance and the short-term perioperative complications.

A total of 50 patients according to the inclusion criteria were selected for the study, who underwent BCS with LEVEL III ALND.

The mean age of the patients studied $=49$ years. (with standard deviation of 7.524 years). Majority of the cases (52\%) were between $35 \& 50$ years of age \& $46 \%$ cases were aged 50 years or above.

\section{5 cases each were reported on the (L) and (R) side.}

Regarding the clinical stage, stage IIA comprised maximum no. of cases i.e. 25 cases (50\%) followed by stage IA with 16 cases $(32 \%)$ and stage IIB with 9 cases (18\%).

The surgical margin of clearance was involved with tumour in 6 cases (12\%). No cases were found to be surgically unresectable.

Among them 12 patients (24\%) were found to have LEVEL III positive nodes.

5 cases out of 12 with LEVEL III POSITIVITY were aged 50 years or above.

In $12 \%$ (6 Cases) all 3 L.N. levels were found to be negative as per HPE report.

$38 \%$ positivity were noted in LEVEL I, $26 \%$ in LEVEL II \& $24 \%$ in
LEVEL III L.N.

LEVEL III L.N. positivity on HPE is significantly higher in ductal CA than in non-ductal CA at $5 \%$ levels.

No. of cases with skip lesions (involvement of higher level of L.N. without the immediate lower one e.g. - involved LEVEL II without LEVEL I) is $3(6 \%)$.

Regarding the type of pathology , INTRADUCTAL CA comprised 34 cases (68\%) on HPE with mean age 51.03 years followed by LOBULAR CA -5 cases $(10 \%)$ with mean age 40.2 years and ADENOID CYSTIC CA - 5 cases (10\%) with mean age of 50 years . $2 \%$ cases were found to be PAPILLARY CA \& 1 $\%$ each of MEDULLARY \& ALVEOLAR types . 4\% cases were found to be of BENIGN pathologies (ANDI , fibroadenoma , etc.) with mean age of 46.5 years.

Regarding the short term perioperative complications , 14 cases $(28 \%)$ with mean age of 49.5 years were without any intra or post operative complications.

Flap necrosis (partial) in 14 cases (28\%) with mean age of 50 years was the most common complication (in contrast to literature where lymphoedema has been implicated to be the most common complication in recent time ${ }^{16}$ ), followed by numbness or paraesthesia in 12 cases $(24 \%)$ with mean age of 46.58 years. Lymphoedema, another major complication was seen in 6 cases $(12 \%)$ with mean age of 48.50 years while seroma in 9 cases ( $18 \%$ ) with mean age of 44.29 years. Only 1 case showed wound infection $(2 \%)$ with culture from wound discharge to be positive for micro organism. The intraoperative complications were seen in the form of haemorrhage in 2 cases (4\%) \& nerve injury (nerve of Bell \&/or thoraco-dorsal nerve) in 3 cases (6\%) who suffered from clinically demonstrable winged scapula or restriction of shoulder joint mobility for which they had to be referred to physical medicine \& rehabilitation.

\section{CONCLUSION:}

Thus the following conclusions can be drawn from this study :1) Clinically negative axilla does not signify absence of pathological lymph node metastasis in any level in early breast cancer patients in this study. 
2) In this study the rate of LEVEL III L.N. positivity is $24 \%$ even in STAGE I \& II (early CA breast).

3) Intraductal CA comprised the bulk of early Breast cancer in this study.

4) Skip lesions to a higher level may be present in lymph nodal metastasis.

5)LEVEL III L.N. positivity per HPE is significantly higher (statistically) in ductal CA than in non-ductal CA at $5 \%$ levels.

6) Early Breast cancer patients can be successfully operated by BCS with level III ALND.

7) MRM with level III ALND may be considered as an alternative to SLNB \& BCS in early CA breast especially in centers where SLNB facilities are not available.

8) Flap necrosis (partial), numbness or paraesthesia , lymphoedema \& seroma fell into the major bulk of complications in this study.

9) The short term complications are not significantly altered in this study as compared to literature.

\section{REFERENCES}

1. Goldhirsch A, Wood WC, Gelber RD, Coates AS, Thurlimann B, Senn HJ: Meeting Highlights: Updated International Expert Consensus on Primary Therapy of Early Breast Cancer. J Clin Oncol 2003, 21(17):3357-65

2. Moore MP, Kinne DW. Axillary lymphadenectomy: a diagnostic and therapeutic procedure. J Surg Oncol. 1997; 66:2-6

3. Tonellotto F, Bergman A, de Souza Abrahao K, de Aguiar SS, Bello MA, Thuler LCS. Impact of number of positive lymph nodes and lymph node ratio on survival of women with node positive breast cancer. Eur J Breast Health. 2019;15: 76-84

4. DiSipio T Rye S, Newman B, Hayes $\mathrm{S}$. Incidence of unilateral am lymphedema after breast cancer: a systematic review and meta analysis. Lancet Oncol.2013;14:500-515

5. Ozaslan C, Kuru B. Lymphoedema after treatment of breast cancer.Am J Surg. 2004;187:69-72

6. Hayes SC, Rye S, Battistutta D, DiSipio T, Newman B. Upper body morbidity following breast cancer treatment is common, may persist longer term and adversely influences quality of life. Health Qual Life Outcomes.2010;8:92

7. Allan W. Silberman, MD, PhD, Carie McVay, MD, [...], and Leslie Memsic, MD. Comparative morbidity of axillary lymph node dissection and the sentinel lymph node technique . Implications for Patients With Breast Cancer. Annals of Surgery.Lippincott, Williams, and Wilkins.

8. Sola M, Recaj M, Castella E, Puig P, Gubern JM, Julian JF, Fraile M. Sentinel node biopsy in special histologic types of invasive breast cancer.J Breast Health.2016; 12:78-82

9. Guven HE, Kulturoglu MO, Gulcelik MA, Ozaslan C. Sentinel lymph node metastasis in invasive lobular carcinoma of breast. Eur J Breast Health. 2018:14:117-120

10. Colakoglu MK, Guven E, Akgul GG, Dogan L, Gulcelik MA. Biological subtypes of breast cancer and sentinel lymph node biopsy. Eur J Breast Health. 2018;14:100-104

11. Elston CW, Ellis IO. Pathological prognostic factors in breast cancer. The value of histological grade in breast cancer: experience from a large study with long-term follow-up. Histopathology 1991;19:403-10

12. Ikeda T. Non surgical ablation therapy for Early stage Breast Cancer.In: Kinoshita T, editor. Surgical procedures in axillary region.Springer; Japan: 2016.p.14

13. Danforth DN Jr, Findlay PA, McDonald HD, Lippman ME, Reichert CM, d'Angelo T, Gorrell CR, Gerber NL, Lichter AS, Rosenberg SA, et al. Complete axillary lymph node dissection for stage I-II carcinoma of the breast. J Clin Oncol. 1986 May; 4(5):655-62.

14. Armando E. Giuliano, MD; Kelly K. Hunt, MD; Karla V. Ballman, PhD; Peter D. Beitsch, MD; Pat W. Whitworth, MD; Peter W. Blumencranz, MD; A. Marilyn Leitch, MD; Sukamal Saha, MD; Linda M. McCall, MS; Monica Morrow, MD. Axillary Dissection vs No Axillary Dissection in Women With Invasive Breast Cancer and Sentinel Node MetastasisA Randomized Clinical Trial . JAMA. 2011;305(6):569-575. doi:10.1001/jama.201 1.90. February 9, 2011, Vol 305, No. 6.

15. Goel AK, Seenu V, Shukla NK, Raina V. Breast Cancer presentation at a regional cancer centre. Natl. Med. J. India. 1995;8:6-9.

16. Preetinder Brar, Satish Jain, and Iqbal Singh .Complications of Axillary Lymph Node Dissection in Treatment of Early Breast Cancer: A Comparison of MRM and BCS . http://www.ncbi.nlm.nih.gov/pmc/articles/PMC3244199/

17. Prognostic and Predictive Factors in Early-Stage Breast Cancer Mary Cianfrocca and Lori J. Goldstein Author Affiliations Fox Chase Cancer Center, Philadelphia, Pennsylvania, USAReceived March 11, 2004.Accepted Mary 21, 2004.

18. Siegel BM, Mayzel MD, Love SM. Level I and II axillary dissection in the treatment of early-stage breast cancer. Arch Surg. 1990;125:1144-7.

19. Veronesi U, Giovanni P, Galimberti V, et al. Sentinel-node biopsy to avoid axillary dissection in breast cancer with clinically negative lymph nodes. Lancet. 1997;349:1864-1867. doi: 10.1016/S0140-6736(97)01004-0. 